Expl Agric. (2019), volume 55 (S1), pp. 107-124 (C) Cambridge University Press 2016. This is an Open Access article, distributed under the terms of the Creative Commons Attribution licence (http://creativecommons.org/licenses/by/4.0/), which permits unrestricted re-use, distribution, and reproduction in any medium, provided the original work is properly cited.

doi:10.1017/S0014479716000442

\title{
IT'S NOT JUST THE TEGHNOLOGY, IT'S THE SURROUNDING SYSTEM: HOW RESEARGHERS IN EGUADOR FOUND WAYS TO MAKE THEMSELVES USEFUL TO FARMERS THROUGH QUINOA AND LUPIN SEED SYSTEMS
}

\author{
By NELSON MAZÓN $\dagger$, EDUARDO PERALTA $\dagger$, ÁNGEL MURILLO $\dagger$, \\ MARCO RIVERAł, ALFONSO GUZMÁN§, NICOLÁS PICHAZACA \\ and CLAIRE NICKLIN ††甘
}

\begin{abstract}
$\dagger$ Programa Nacional de Leguminosas y Granos Andinos, Estación Experimental Santa Catalina, Instituto Nacional Autónomo de Investigaciones Agropecuarias (INIAP). Panamericana Sur, km 1. Quito, Ecuador, $\ddagger$ Universidad Técnica de Cotopaxi, Latacunga, Ecuador, §Gobierno Provincial Autónomo Descentralizado de Chimborazo, Riobamba, Ecuador, Asociación de Productores de Semilla y Alimentos Nutricionales Andinos - Mushuk Tuyay (APROSANAMY), Cañar, Ecuador and $\dagger \dagger$ Collaborative Crop Research Program, Francisco Salazar 360, Quito, Ecuador
\end{abstract}

\section{(Accepted 6 March 2016; First published online 13 July 2016)}

\begin{abstract}
SUMMARY
Agriculture research often focuses on a technical problem. However, the most effective researchers usually intuit that this entry point is not sufficient to make themselves useful to farmers and nudge systems. Yet non-technical work frequently goes undocumented leaving many of the drivers of success unstudied. This paper attempts to understand the factors that contributed to the wide utilization of native crop varieties and species that were being promoted by the Ecuadorian National Agriculture Research Institution. The results show that what really made a difference in farmers' lives and the overall food system was increasing farmers' knowledge and capacity to produce quality seeds, promoting the consumption of these crops to national consumers, and linking farmers to outside groups. As a result, over a period of five years three case studies on three different farmer groups showed adoption rates of new varieties of between 20-50\% and that they were able to produce approximately $7.5 \%$ of the annual demand for quinoa and lupin seed in Ecuador, from a starting point of virtually nothing. The research shows that the added value of a research institution might not be known at the beginning of the intervention, but rather will emerge over time through dialogue and negotiation based on systematic understanding of the context. Therefore, an appropriate stance for external organizations is to begin with an awareness of the existing assets of a specific farmer group and provide options that can be leveraged by local communities.
\end{abstract}

\section{INTRODUGTION}

Capitals as context

This research explores through three case studies how different methodological options for working with communities to test and multiply seeds interact with different farmer contexts. These options include Farmer Field Schools (FFS), Local Agriculture

ł†Corresponding author. Email: cnicklin@andescdp.org 
Research Committees (LARCs) and demonstration plots. Specifically, we will use Capitals Frameworks to think about how different research options responded to various organizational contexts. The Community Capitals Framework, for instance, uses seven capitals to help understand the assets of communities and organizations that can then be invested in their future success (Emery and Flora, 2006). The seven capitals are: natural, cultural, human, social, political, financial and built. Within social capital, a distinction between bonding and bridging social capital can be made (Nayaran, 1999). Bonding social capital refers to strong connections that often bind together one's social and/or kin group. Bridging social capital, on the other hand, refers to the weak ties that exist between groups and allow for ideas and technologies to spread more widely (Granovetter, 1973). The Wealth Creation Framework uses eight capitals, including 'intellectual capital', that is especially useful for thinking about participatory research and seed systems (Castelloe et al., 2011). Intellectual capital is defined as:

\footnotetext{
the stock of knowledge, innovation, and creativity among people in a community or region. Intellectual capital is embodied... in the enduring intellectual products that... individual minds create. Intellectual capital includes various kinds of standards, frameworks, models, and approaches that spread from one leader, organization, or network to another. Intellectual capital is about institutionalizing shared knowledge, new ways of seeing, and new ways of working (Castelloe et al., 2011).
}

Lastly, Gutiérrez-Montes (2005) has shown that one or two capitals can be invested or leveraged to build the other capitals to create an 'upward spiral' of sustainable development.

The question that guides this research is: In what ways can understanding local capitals allow research institutions to tailor participatory research and extension options and to leverage existing assets in order to contribute to an upward spiral of sustainable development? In this case, the intervention centres on improving seed systems to address different farmers' needs.

\section{Andean grains}

Andean grains ${ }^{1}$ such as quinoa Chenopodium quinoa, lupin Lupinus mutabilis, and amaranth Amaranth spp. are important species in the agro-food systems of smallscale farmers in the Ecuadorian highlands. Quinoa and amaranth have high levels of quality proteins and lupins are one of the only sources of essential fats in the Andean diet (Council, 1989). They are also fundamental to Andean farming rotations, which were developed over thousands of years to preserve the delicate fertility of mountainregion soils (Franco and Main, 2008). However, colonization of Latin America by the Spanish in the 16th century is largely credited with a long process of devaluing these crops (Council, 1989). It is a testament to the resilience and strength of local cultures that Andean grains have survived until the current era, and have now become the focus of increased demand, initially by foreign consumers interested in their health

\footnotetext{
${ }^{1}$ Quinoa, lupin and amaranth are often referred to as Andean grains, although quinoa and amaranth are technically pseudo-cereals and lupin is a legume.
} 
Table 1. Comparison between selected varieties and local landraces of quinoa, lupin and amaranth grown in farmers' fields and research stations in the central highlands of Ecuador between 2002 and $2010^{*}$.

\begin{tabular}{|c|c|c|c|c|c|c|c|}
\hline & & \multicolumn{2}{|c|}{ Lupin } & \multicolumn{2}{|c|}{ Quinoa } & \multicolumn{2}{|c|}{ Amaranth } \\
\hline & & $\begin{array}{l}\text { INIAP } 450 \\
\text { Andino }\end{array}$ & $\begin{array}{l}\text { Local } \\
\text { ladrase }\end{array}$ & $\begin{array}{l}\text { INIAP } \\
\text { Tunkahuan }\end{array}$ & $\begin{array}{l}\text { Local } \\
\text { ladrase }\end{array}$ & $\begin{array}{l}\text { INIAP } \\
\text { Alegria }\end{array}$ & $\begin{array}{l}\text { Local } \\
\text { ladrase }\end{array}$ \\
\hline \multicolumn{2}{|l|}{ Provenance } & Peru & Ecuador & Ecuador & Ecuador & Peru & Ecuador \\
\hline \multirow[t]{2}{*}{$\begin{array}{l}\text { Days to harvest } \\
\text { (average) }\end{array}$} & $\begin{array}{l}\text { Experimental } \\
\text { field }\end{array}$ & 188 & 260 & 180 & 214 & 119 & 183 \\
\hline & Farmer field & 223 & 279 & 201 & & & \\
\hline \multirow[t]{2}{*}{$\begin{array}{l}\text { Yield average } \\
\qquad\left(\mathrm{kg} \mathrm{ha}^{-1}\right)\end{array}$} & $\begin{array}{l}\text { Experimental } \\
\text { field }\end{array}$ & 1166 & 2251 & 1893 & 1025 & 2308 & 890 \\
\hline & Farmer field & 1377 & 616 & 976 & & 1200 & \\
\hline \multicolumn{2}{|c|}{$\begin{array}{l}\text { Resistance to anthracnose } \\
\text { (only effects lupin) }\end{array}$} & susceptible & susceptible & - & - & - & - \\
\hline \multicolumn{2}{|c|}{$\begin{array}{l}\text { Resistance to downy mildew } \\
\text { (only effects quinoa) }\end{array}$} & - & - & intermediate & susceptible & - & - \\
\hline
\end{tabular}

Source: INIAP

*This table is meant as background for the reader to get a sense of the advantages of the selected varieties, not as research findings, there is not detailed information available about how many landraces were tested or how they were selected. The farmers provided some of the accessions, most were from the INIAP collection. This work was done in the process of selecting the specific varieties mentioned as the most promising. The local landrace column can represent an average of over 20 landraces all the numbers represent averages over many years and plots.

benefits, but now in national and local markets as well (Horton, 2014). Whilst Andean farmers have domesticated many crops over the millennia, including Andean grains, and have also developed many landraces, formal breeding programmes offer the opportunity to contribute selected and bred varieties that have higher yield potential to respond to current demands. Nonetheless, often formal breeding and seed selection programmes hosted by National Research Institutions fail to produce varieties that are widely adopted by farmers. Reasons for limited adoption of new varieties in general can include that the varieties don't respond in farmer conditions, are not resilient, do not have the culinary qualities farmers desire or are not widely available (Almekinders et al., 1994).

In the hopes of avoiding this situation, for over a decade, The National Legume and Andean Grains Research Program (PRONALEG-GA) of the National Agricultural Research Institute of Ecuador (INIAP), has used participatory research methods to evaluate, validate and disseminate technologies for the production of Andean legume and pseudo-cereal crops, known as Andean grains. INIAP's interventions have centred around the implementation of mixed (formal and informal) seed multiplication and distribution systems of selected quinoa (INIAP Tunkahuan), lupin (INIAP 450 Andino) and amaranth (INIAP Alegría) varieties. These varieties were selected through a rigorous characterization of INIAP's germplasm collection consisting of 529 accessions of lupin, 434 of amaranth and 608 of quinoa by cultivating and evaluating them first in INIAP's test fields and later in farmer fields. This work is summarized in Table 1 and serves as background context to the focus of this paper which is the promotion and use of these three varieties. 
Since the end of the 1990s, INIAP'S PRONALEG-GA has served as a reference for the small but growing group of people who were interested in Andean grains. Over the years, the programme has contributed to the expansion in both the demand and supply of Andean grains in Ecuador (Horton, 2014). PRONALEG-GA has undertaken research in the production, post-harvest, value-added and nutrition of Andean grains. It has also engaged in multiple strategies to promote the consumption of Andean grains in both rural and urban areas, through mechanisms such as workshops, radio advertising and culinary fairs. A Value Chain Workshop for Andean grains sponsored by PRONALEG-GA in 2006 with the participation of 60 actors, including farmers and processors produced a listserve of 'friends' of Andean grains where members could share their requirements and offerings of Andean grain seed. This later became an important source of seed market contacts for farmer seed producers. These strategies seek to map and integrate market opportunities, which are an essential part of establishing sustainable seed supply systems (Witcombe et al., 2010). Moreover, the programme can be seen as an important source of bridging social capital amongst the larger Andean grains community.

\section{Seed systems}

Many aspects of seed quality are inconspicuous or invisible to farmers, and as a result formal and informal seed systems have evolved to provide some assurance to farmers about seed quality in terms of germination, absence of diseases and pest, and purity or cleanliness, as well as, genetic qualities (Almekinders et al., 1994). Formal systems are usually managed by the public sector and involve certification processes designed to provide high germination rates and true-to-type seed. Informal systems rely on knowing and trusting the seed provider (Badstue, 2007).

The PRONALEG-GA group of INIAP decided that since formal seed systems for even principal crops like potato only provided approximately $5 \%$ of seed (Thiele, 1999), and minor crops like quinoa and lupin didn't even have seed quality parameters or formal systems when they began, decided to use a non-conventional, integrated or a mixed seed system, based largely on pragmatism and being influenced by The International Potato Center's work on mixed seed systems for potato. In mixed seed systems, farmers develop strategies to produce and distribute seeds in ways that approach those of the conventional system; however, these mixed systems follow rules and regulations that are more appropriate to their production, organizational and livelihood contexts. For example, mixed systems do not rely on formal standards such as undergoing laboratory testing or expensive inspection regimes (Louwaars, 1994).

Mixed seed systems can also be viewed through a capital lens. Bonding social capital is at the centre of traditional seed systems where seed flows along trusted networks often related to kinship or ethnicity (Stromberg et al., 2010). Meanwhile, in formal seed systems, certification allows for more bridging between unknown parties, but is often not effective because the cost, quantity and/or characteristics of the seed reduce supply and demand (lack of financial, natural capital). The bridging social capital in mixed seed systems allows otherwise isolated groups to connect using 
weaker but wider networks than found in traditional seed systems. The strengthening of mixed systems led by farmers' organizations and supported by a formal research entity like INIAP calls for the use of a participatory and transparent research process that facilitates collaboration between different types of actors.

\section{Participatory research approaches as options}

The participatory research methodologies used and adapted by INIAP included Farmers' Field Schools (FFS) and Local Agricultural Research Committees (LARCs). In general, FFS and LARGs promote farmer-centred agricultural research for innovation and decision-making (Braun et al., 2000). The FFS methodology facilitates ecological learning and technological innovation for the sustainable improvement of agriculture; however, its objective is not just the research and adoption of technologies but also the generation of leadership amongst the farmers in order to resolve ever more complex challenges (Pumisacho and Sherwood, 2005). LARGs are farmerdirected research projects that aim to satisfy the research needs of rural communities where access to agricultural and extension services is limited. They are a means to evaluate, adapt and accelerate the propagation of technological options such as new varieties, to farmers' contexts (Ashby, 2001). The focus on leadership, capacity and learning in FFS can be seen as an investment in human capital whereas LARCs are more focussed on increasing natural capital through new technologies. Both are engaged in forming intellectual capital. The use of these methodologies by INIAP was largely dictated by happenstance, but in hindsight the Options by Context $(\mathrm{OxC})$ framework, championed by the Collaborative Crop Research Program of the McKnight Foundation ${ }^{2}$ and the World Agroforestry Centre (ICRAF), helps to explain which research approaches worked where and why. Within an $\mathrm{OxC}$ framework, researchers seek to provide and test various Options in multiple Contexts, where the farmer is in charge of her or his own decisions and adaptations. This process stands in contrast to a wide adoption approach that has predominated in the past where one technology was the focus of blanket recommendations over large areas and therefore often not relevant to small-scale farmers (Baranski, 2015; Snapp et al., 2003). The idea of $\mathrm{OxC}$ is often used to refer to technological options fitting farmers' contexts. However, the $\mathrm{OxC}$ framework can also be applied to how outside research institutions interact with a community. Similar to providing different technological options to farmers, INIAP has expanded methodological Options, such as LARCs and FFS, for different farmer research Contexts.

\section{METHODS}

The main method used in this research is the case study, which is especially appropriate when trying to synthesize various sources of information and data and interpret them within a specific context. Robert Yin (2009) writes that 'case studies

\footnotetext{
${ }^{2}$ See http://aeix3dev.devcloud.acquia-sites.com/principle/option-context-interaction-generalisation-genotypeenvironment-interaction
} 


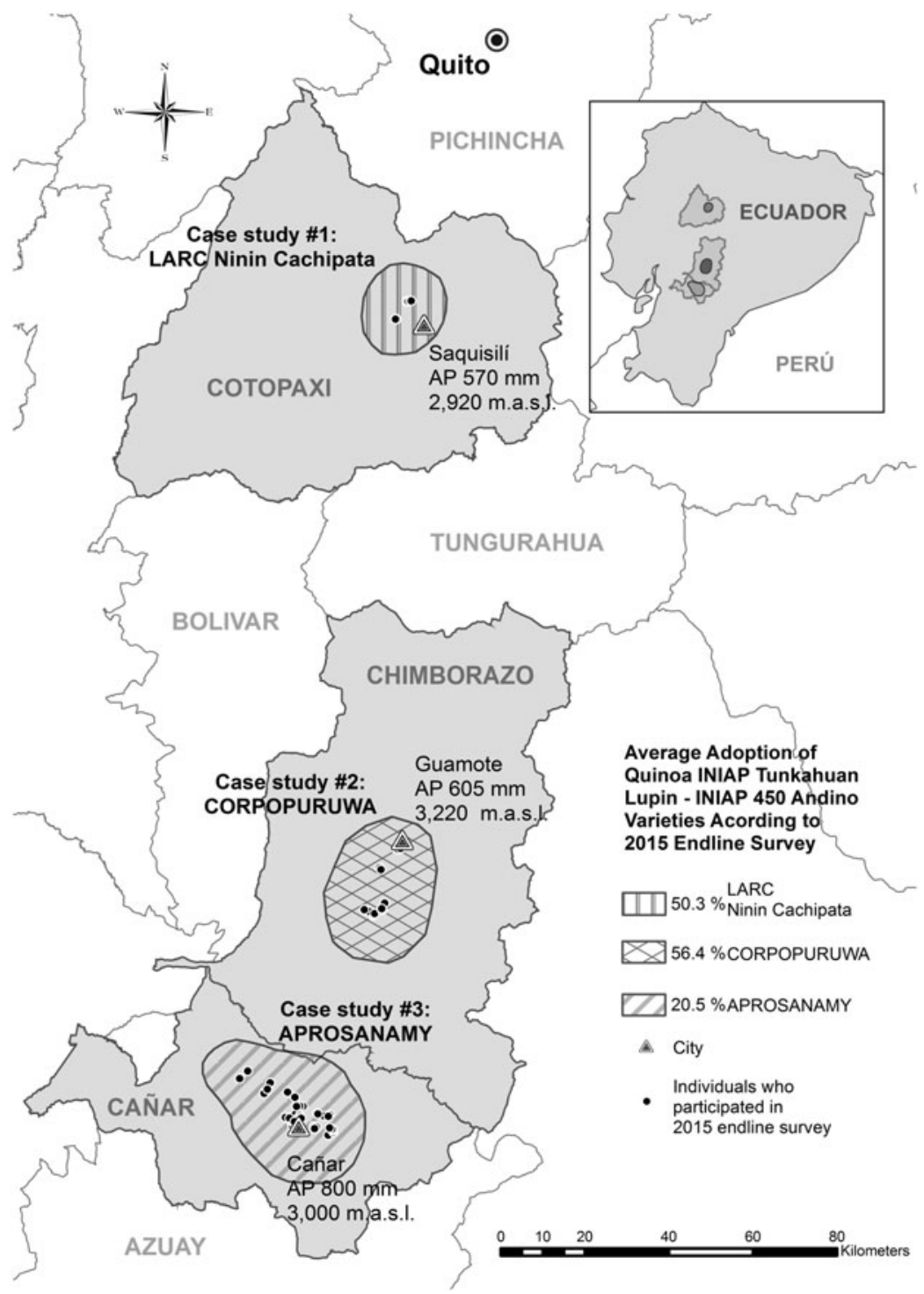

Figure 1. Map of the three INIAP intervention areas for dissemination of the new selected varieties of quinoa and lupin and their adoption rates. $\mathrm{AP}=$ annual precipitation.

are the preferred method when (i) "how" or "why" questions are being posed, (ii) the investigator has little control over events and (iii) the focus is on a contemporary phenomenon within a real-life context'. The three case studies correspond to the three farmers groups shown in Figure 1. The case studies are largely informed by oral histories of farmer groups with reference to community capitals; annual registries of seed production volumes to examine impacts on seed supply; baseline and endline surveys of selected farmers to determine use and adoption of seeds and varieties and 
Table 2. Level of participation of the surveyed people in the project activities in 2009 assessed by key informants in 2014 .

\begin{tabular}{lllll}
\hline & \multicolumn{3}{c}{ Type of participation in the project } & \\
\cline { 2 - 4 } Project area & High & Intermittent & Low & Total \\
\hline Saquisili, Cotopaxi & 7 & 40 & 10 & 57 \\
Guamote, Chimborazo & 38 & 47 & 12 & 97 \\
Cañar, Cañar & 27 & 59 & 73 & 159 \\
Total & $\mathbf{7 2}$ & $\mathbf{1 4 6}$ & $\mathbf{9 5}$ & $\mathbf{3 1 3}$ \\
\hline
\end{tabular}

an external developmental evaluation (Horton, 2014). In the case method, part of the evaluative research consists in describing the context of each of the three cases and their histories of interactions with INIAP. The developmental evaluation expert Dr. Michael Q. Patton writes, 'as the developmental evaluator goes from situation to situation, his or her first task is to describe and interpret the innovation anew in each locale, perhaps taking into account factors unique to that locale or series of events'. (2011, p. 164) It is important to note that INIAP interacted with these cases through a variety of projects supported by external donors that often went beyond seed system work and included general promotion and support for Andean Grain production and consumption. The baseline and endline information is connected to those general projects, of which seed systems development was one aspect.

The seed production registries were maintained by each organization and compiled annually by INIAP. The baseline evaluation was carried out in 2009 and included 313 surveys: 57 in Cotopaxi, 97 in Chimborazo and 159 in Cañar. In all three provinces, convenience samples were used. In the communities of Cotopaxi, the selection of people was done through snowball sampling where those surveyed would suggest other people to be surveyed. In Chimborazo, the surveys were done with people who expressed interest in the project; and in Cañar, the surveys were done with people easily encountered by the surveyors and who agreed to respond to the survey. Table 2 describes different strata in levels of intensity of participation in the INIAP project on Andean grain production that occurred in the baseline study. These levels of participation were determined by local implementers ex-post in 2014.

Whilst acknowledging the fact that the baseline sample was not representative of the population of farmers who use Andean grain seed, we interviewed a subset of the same respondents in the endline in order to measure change over time. The endline sample was chosen to match the strata of participation levels exhibited by the baseline sample, and we set out to include 25 interviewees for each participation level per project area from the baseline. Since it was not always possible to fulfil these parameters, a sample of 154 surveys was obtained, as shown in Table 3. The geographic distribution of endline informants is shown in the map in Figure 1. Even though the information is not fully representative of the target population, the fact that the study used a methodology based on a panel of interviewed parties makes it possible to estimate differences over time for this group. We therefore felt justified 
Table 3. Number of endline surveys based on the level of participation in the project and by area 2015.

\begin{tabular}{lllll}
\hline & \multicolumn{3}{c}{ Level of project participation } \\
\cline { 2 - 4 } Project area & High & Medium & Low & Total \\
\hline Saquisili, Cotopaxi & 5 & 31 & 5 & 41 \\
Guamote, Chimborazo & 22 & 15 & 10 & 47 \\
Cañar, Cañar & 25 & 20 & 21 & 66 \\
Total & $\mathbf{5 2}$ & $\mathbf{6 6}$ & $\mathbf{3 6}$ & $\mathbf{1 5 4}$ \\
\hline
\end{tabular}

in interpreting the endline as measuring changes over time in each of the groups as well as changes that can be observed between the groups. Also, the overlap between project participation and seed system participation is assumed to be close to $100 \%$ since all participants received seed.

Lastly, in addition to the longitudinal approach of monitoring change over time, in 2013, an external consultant, Dr. Douglas Horton, evaluated the Andean Grains Project implemented by PRONALEG-GA of INIAP. The evaluation also used a case study approach that encompassed the three cases described in this paper but its unit of analysis was an Andean Grains project implemented by INIAP, not necessarily the three cases in this paper. The Horton evaluation was based on non-published reports of PRONALEG-GA; published literature; field work in Ecuador, including visits to the sites where the activities were performed and interviews of key informants; as well as participatory review workshops at the beginning and end of the visit (Horton, 2014).

\section{RESULTS}

The following section uses a Capitals Framework to discuss the background on the three case studies, describe INIAP's interventions and present the results of those interventions in terms of seed use, multiplication and dissemination. Specifically, we will look at: (i) the starting capital that existed in the communities prior to the intervention by INIAP, (ii) capitals that were developed through the collaboration with INIAP and (iii) how and when those capitals were leveraged to improve other capitals. This presentation of oral history and description of the interventions is part of the results per the case study method, which has been applied to all three farmer groups. Culturally, the three areas are comprised of predominantly indigenous small-scale farmers located in the Cotopaxi, Chimborazo and Cañar provinces (Figure 1). In terms of financial capital, according to the latest public statistics (SIISE, 2015), the poverty index ${ }^{3}$ in the three intervention counties is $76 \%$ in Cañar, $95 \%$ in Guamote (Chimboarazo) and 84\% in Saquisilí (Cotopaxi). The lower incidences in

\footnotetext{
${ }^{3}$ The methodology used to determine the poverty index was defined by the Andean Community of Nations and consists of households presenting certain characteristics related to the physical properties of their housing (e.g. temporary structures), lack of basic services, high levels of economic dependency on someone who has less than 2 years of education, children who do not attend school or severe overcrowding.
} 
both Cañar and Cotopaxi can probably be partially attributed to the high levels of migration and off-farm labour available (human capital).

\section{Case study \#1: local agricultural research committee (LARC) of ninin cachipata}

In 2000, INIAP started working with 14 farmers from the Ninin Cachipata community to promote and produce INIAP 450 Andino lupin variety seeds. The existing cultural capital in Ninin Cachipata was unknown to INIAP for many years and had implications for the scale of the intervention. It turned out that the community cleaved along religious affiliations and although INIAP was open to working with any farmers, it inadvertently ended working within a network of Evangelical farmers. This had advantages in that the group had high levels of bonding social capital and they became a group of very dedicated collaborators. However, the failure of the interventions to reach a wider audience can probably be attributed to Catholic members of the community feeling excluded from INIAP's work and the lack of bridging capital between the two groups. If INIAP had been aware of these different contexts at the beginning of the intervention, it could have developed different strategic options for engaging the two groups.

Starting in 2005, INIAP widened its intervention to another four communities within the county of Saquisili through the establishment of more LARGs. With these groups, INIAP evaluated and selected not just lupin but also varieties of quinoa, potatoes, peas and barley. Other experiments were also performed, such as the evaluation of organic fertilizers, sowing systems and the effect of green manure on potato cultivation. This learning process increased the intellectual capital of both the farmers and INIAP. Starting in 2009, in order to share the experiences of the five communities even more broadly, demonstration plots and seed multiplication processes were implemented in other localities in the Saquisili and Latacunga counties.

Of the five LARGs, only the Ninin Cachipata LARC maintained interest in Andean grain seed systems after the initial research cycle ended. They continue to produce and distribute seeds, particularly of the INIAP 450 Andino variety of lupin. This might be partly attributed to the donation of a threshing machine by INIAP. The intellectual capital of how to produce high quality seeds combined with the contacts INIAP provided them (social bridging capital) and built capital in the form of a thresher were then leveraged to increase their financial capital through the sale of high quality lupin to other farmers in the Saquisilí county and sporadically to outside farmers, as well as, to state and private institutions.

Case study \#2: corporation of andean legume and grain producers of the puruwa chimborazo people (CORPOPURUWA)

INIAP began to work in the county of Guamote in 2008 with the broad objective of promoting the production and consumption of the selected varieties of lupin and quinoa. In order to spur local seed systems for these varieties, $5 \mathrm{~kg}$ of lupin seed (INIAP 450 Andino variety) and $1 \mathrm{~kg}$ of quinoa seed (INIAP Tunkahuan variety) 
were distributed to representatives of 12 communities in the county of Guamote. Of the 12 communities, four showed interest in continuing to work with INIAP on Andean grains. The starting political capital of those four communities was different than the rest in that they had privatized all of their land, where in the other eight communities, there were still communal lands that might have provided disincentives for market opportunities. FFS were established in each of the four communities beginning with a training of trainers course. The participants in the FFSs, through their own initiative, decided to associate into a seed producing Corporation, which became CORPOPURUWA consisting of 62 founding members (social capital).

CORPOPURUWA has the most sophisticated or advanced mixed seed system of the three case studies. It has developed three local seed banks (built capital) and a participatory quality guarantee system (intellectual capital). In 2011, CORPOPURUWA developed a brand for their product 'Semillas del Desierto', or Seeds of the Desert referencing their location in the Palmira desert, as a way of differentiating their seed in the market (Mazón et al., 2011). In 2014, with the support of Ministry of Agriculture (MAGAP) and the Food and Agriculture Organization (FAO) of the United Nations, CORPOPURUWA was recognized as a seed certifier and has started to produce and distribute certified seeds of improved varieties of lupin, quinoa and barley. The seed users are the farmers in their communities and the county, as well as government projects, private companies, development organizations and farmers from other regions of the country. Often the initial contact to these markets and buyers came from PRONALEG-GA.

CORPOPURUWA has been able to leverage additional support (human, social, built and financial capitals) from the Indigenous Fund (infrastructure, equipment, working capital), FAO (infrastructure, equipment and training to generate added value), MAGAP (associativity, infrastructure, equipment, supplies) and from the Provincial Government of Chimborazo (equipment, supplies, commercialization).

Case study \#3: association of andean seed and nutritional food producers mushuk yuyai (APROSANAMY)

APROSANAMY is a private, not-for-profit foundation, comprised of indigenous farmers and professionals, created in 1994. Thus, it had significant social capital prior to its collaboration with INIAP. APROSANAMY focusses on facilitating agroecological production with an emphasis on local market development and food sovereignty. This orientation can be seen as part of its pre-existing cultural capital. It promotes production of the quinoa, barley, amaranth and lupin species (amongst other crops) that by the middle of the 20th century had practically disappeared from its territory. The Association receives and processes these crops to produce value added products that are sold in communal stores, educational centres and sales outlets throughout the city of Cañar.

INIAP was approached by the leaders of APROSANAMY in 2009 to help them promote the cultivation and consumption of Andean grains. The training strategy was similar to that used in other the project areas and involved a mix of FFS, 


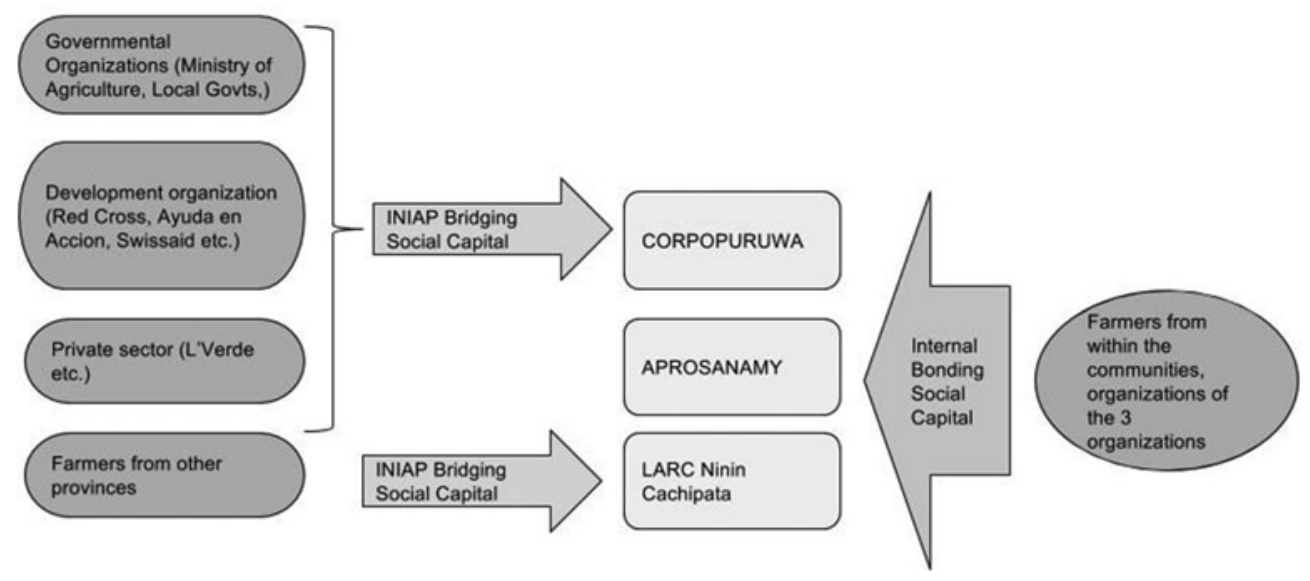

Figure 2. Diagram of bridging social capital of INIAP in brokering seed sales with the three associations and the bonding social capital of seed exchanges within organizations and communities.

demonstration plots, workshops, field days and demonstration fairs. The collaboration focussed primarily on production and distribution of high quality seed, specifically with a mixed seed system approach. The seed producers of APROSANAMY provide quinoa, barley, amaranth and lupin seed to their members and collect the production at their small food processing plant. In addition to support from INIAP, APROSANAMY has had grants from the Andean Community of Nations, Manos Unidas and MAGAP, with whose funds it purchased equipment to strengthen the processing plant and acquired a threshing machine to facilitate the harvest of the seed lots and commercial grains (financial and built capitals).

Figure 2 summarizes some of the seed system bridging social capital ties brokered by INIAP and the bonding ties developed within communities and organizations.

\section{Seed production}

Since 2009, the seed producing organizations of the Ninin Cachipata, Guamote and Cañar counties have produced a total of $75700 \mathrm{~kg}$ of lupin, quinoa and amaranth seed. Of the three organizations, CORPOPURUWA stands out with 73\% of the total volume of seed production. In terms of the crops, the greatest volume is for lupin with $61748 \mathrm{~kg}(81 \%)$, followed by quinoa with $13392 \mathrm{~kg}(18 \%)$, and in third place, amaranth, with only $560 \mathrm{~kg}$. Since amaranth numbers are still very low they are not included in the following results. However, amaranth has seen meaningful gains in the sense that this promising crop had all but disappeared from farmers' fields by the $1990 \mathrm{~s}$, and it is expected that there will be large increases in demand over the next decade as its properties become better known in national and international markets.

Using the 2014 numbers shown in Figures 3 and 4, enough seed was produced that year to cover 454 hectares of lupin and 335 hectares of quinoa ${ }^{4}$. Based on

\footnotetext{
${ }^{4}$ We used the conversion figures of $50 \mathrm{~kg}$ of lupin seed and $12 \mathrm{~kg}$ of quinoa to plant 1 ha (Peralta, et al., 2014).
} 


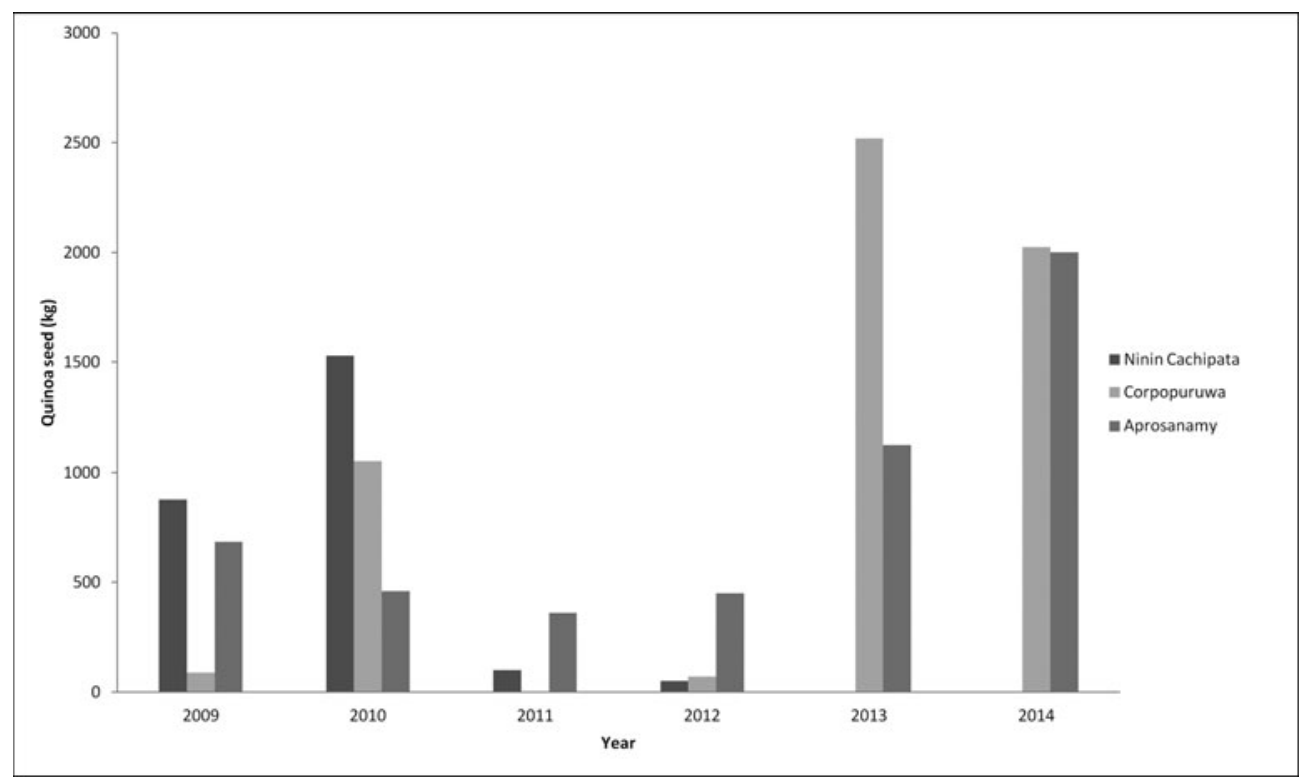

Figure 3. Quantity of quinoa seed $(\mathrm{kg})$ per year produced since 2009 by three seed production organizations in the Ecuadorian highlands.

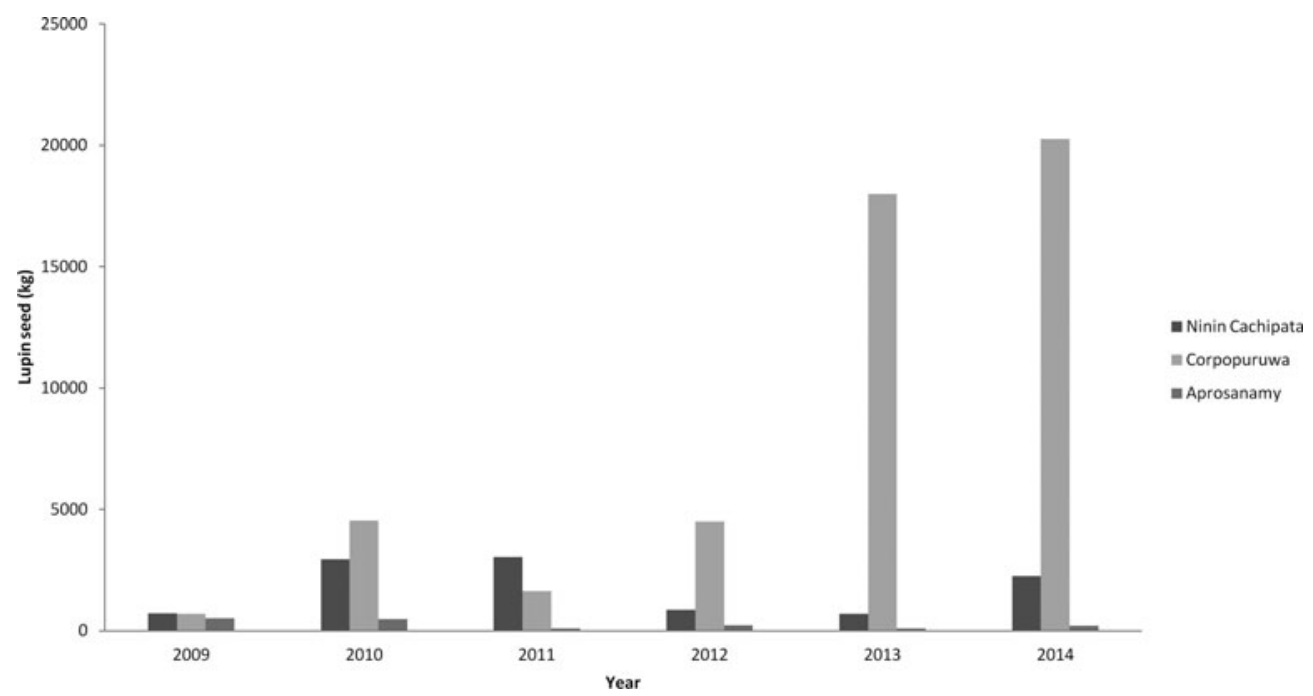

Figure 4. Quantity of lupin seed (kg) per year produced since 2009 by the three seed production organizations in the Ecuadorian highlands.

the data from the last agricultural census (Junovich, 2003), in the case of lupin, this would cover 8\% of national demand for seeds for this crop. Using estimates of the area planted with quinoa in 2014 (5000 ha according to MAGAP projections), 
the seed would provide coverage for $7 \%$ of the quinoa area currently planted in $2014^{5}$.

CORPOPURUWA and the Ninin Cachipata LARG give priority to lupin seed production (90 and 80\% of total seed produced, respectively), whilst APROSANAMY produces primarily quinoa seed (71\% of the total produced). This can be explained by the different agroecological conditions (existing natural capital). Ninin Cachipata and CORPOPURUWA have drier conditions that favour lupin production, whilst the higher rainfall in Cañar is more suitable for quinoa production. Moreover, in the provinces of the southern highlands of the country (including Cañar), consumption of lupin has been culturally marginal and is in the process of being reintroduced. By contrast, in the Northern Sierra, lupin was always a popular street food and consumption has only increased since the early 2000s (Nicklin et al., 2006). These culinary preferences are part of the existing cultural capital of each area.

In addition to producing selected seeds, CORPOPURUWA also produces certified quinoa and lupin seeds. In 2014, 55\% of their lupin seed and 100\% of their quinoa seed achieved certification by MAGAP. An increase in the quinoa seed supply can be observed since 2013 (except in Ninin Cachipata, where it has become non-existent), which responds to increased demand for this crop related to the celebration of the International Year of Quinoa promoted by the FAO and the implementation of MAGAP's Quinoa Production Promotion Project (Figure 3).

In the case of lupin, CORPOPURUWA's supply of seeds has shown sustained growth over the last 3 years. The stability of the high market price for the grain has increased interest in this crop with the consequent higher demand for seeds. CORPOPURUWA is the organization that has best responded to this increased demand, including with certified quality seeds. Ninin Cachipata's seed supply remained stable, except in 2012 and 2013 mostly due to poor climatic conditions. APROSANAMY's supply of lupin seeds is marginal (Figure 4).

\section{Seed distribution}

For the most part the organizations use three distribution methods for the seeds: sales, loans and barter. These pathways are informed by networks created by bridging and bonding social capital as well as cultural capital. CORPOPURUWA and the Ninin Cachipata LARC distribute the seeds principally via sales. In the case of CORPOPURUWA, seed dissemination has been broader, reaching not just the Chimborazo province but also other provinces of the central and northern highlands of the country, including farmers, national government projects, local governments, development organizations and companies (bridging social capital). The Ninin Cachipata LARC has sporadically sold seed in regions outside of its areas of influence, but its main market is local farmers. Normally, the seeds receive a price premium based on the current price of the commercial grain in local and wholesale markets.

\footnotetext{
${ }^{5}$ MAGAP's projections are more recent and accurate than using the 2003 census to estimate demand. Unfortunately, since lupin is still a very minor crop in Ecuador, there is no data available on demand so the census information is being used as an imperfectly low indicator.
} 
Table 4. Percentage difference between the endline (2015) and baseline (2009) in production and sowing frequency of lupin and quinoa in general and INIAP varieties specifically amongst the farmers surveyed in three farmers' groups.

\begin{tabular}{lllll}
\hline & $\begin{array}{l}\text { Total } \\
\left(n=132^{*} / 289^{\dagger}\right)\end{array}$ & $\begin{array}{l}\text { LARC NG } \\
(\text { Cotopaxi }) \\
\left(n=19^{*} / 33^{\dagger}\right)\end{array}$ & $\begin{array}{l}\text { CORPOPURUWA } \\
(\text { Chimborzo }) \\
\left(n=47^{*} / 95^{\dagger}\right)\end{array}$ & $\begin{array}{l}\text { APROSANAMY } \\
(\text { Cañar }) \\
\left(n=66^{*} / 159^{\dagger}\right)\end{array}$ \\
\hline Grow lupin & $19 \%$ & $5 \%$ & $28 \%$ & $11 \%$ \\
Grow Andino 450 & $33 \%$ & $15 \%$ & $67 \%$ & $10 \%$ \\
Grow quinoa & $29 \%$ & $-5 \%$ & $45 \%$ & $24 \%$ \\
Grow Tunkahuan & $30 \%$ & $14 \%$ & $29 \%$ & $26 \%$ \\
\hline
\end{tabular}

${ }^{*}$ number of individuals in the endline survey; ${ }^{\dagger}$ number of individuals in the baseline.

For example, in 2014, CORPOPURUWA sold lupin seed for US\$150/45 kilos whilst grain lupin was selling for between US $\$ 110$ and US $\$ 120$ representing a premium of at least $36 \%$. This represents a leveraging of intellectual and natural capital to increase financial capital. Similar prices were received by the producers in Ninin Cachipata. In the case of APROSANAMY, loans are the main distribution mechanism that are then repaid at the end of the season through deliveries to the processing plant and are more predicated on bonding social capital amongst association members. To a lesser degree, all three organizations share seeds, observing the ancestral practices of reciprocity and solidarity, such as through barter, gifting or in exchange for labour (cultural capital and bonding social capital).

\section{Farmer utilization}

In aggregate, we documented an increase in sowing frequency and in the use of improved varieties of lupin and quinoa amongst farmers who participated in the surveys in the project area of influence (Figure 1). However, the specific variations amongst the three sites also reveal interesting patterns in terms of matching technological options with local contexts (Table 4).

Indeed, the results presented in Table 4 are not uniform for the three organizations. The greatest impact in terms of crop and variety adoption was in CORPOPURUWA. The results for APROSANAMY are similar to those of CORPOPURUWA, but with less increase in use of lupin. Moreover, there is less of an increase in people growing quinoa in APROSANAMY, where the farmers already produced quinoa. The slightly lower rise in the use of Tunkahuan can be explained by pre-2009 introduction of the variety by a leader of APROSANAMY who worked with INIAP for many years in the 1990s. In the case of Ninin Cachipata, the survey of 2009 resembled an endline survey more than a baseline: INIAP's activities in Ninin Cachipata began in 2000 and were mostly completed by 2008 . The 2015 survey in turn, serves as an interesting examination of the sustainability of the changes 7 years ex-post. Thus, the percentage decrease in the number of farmers growing lupin and quinoa represents the sustainability after the interventions ended, which when seen from this perspective is quite impressive, with only quinoa showing signs of disuse. It is also interesting to 


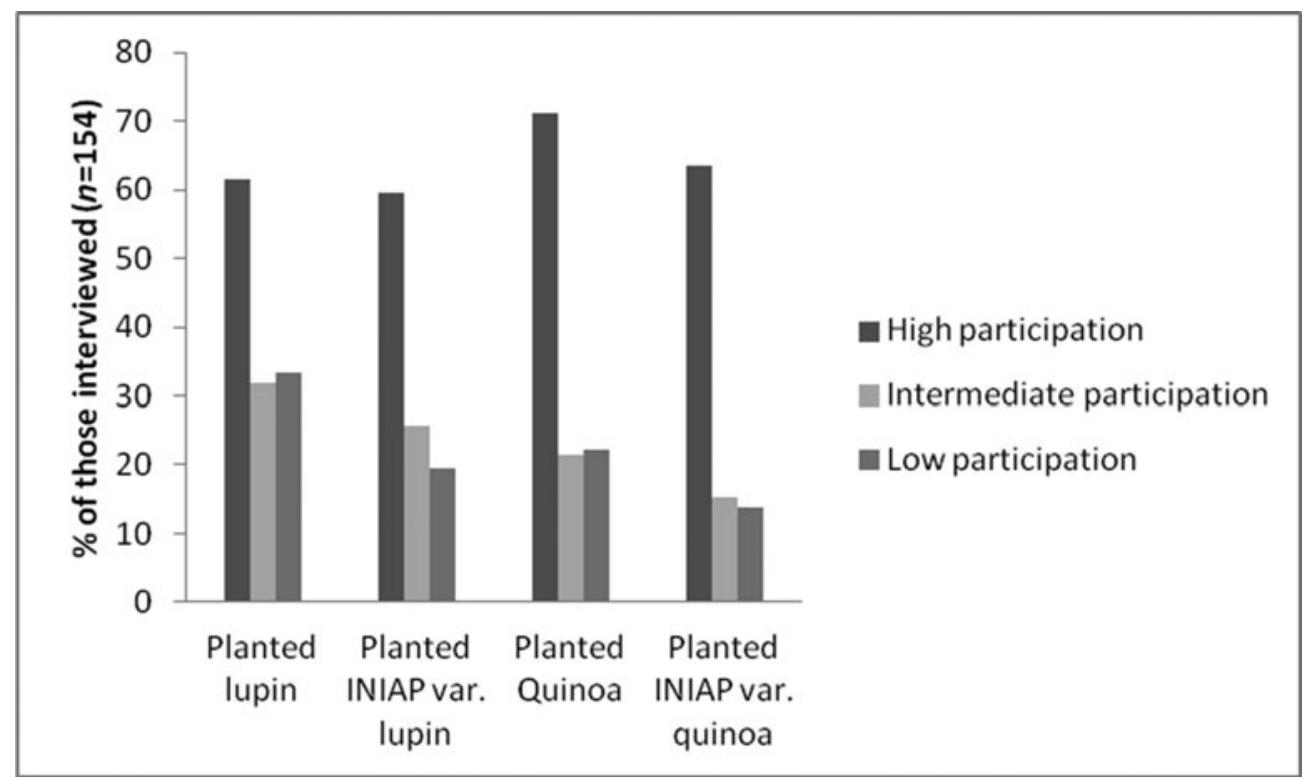

Figure 5. Frequency of sowing and utilization of lupin and quinoa varieties between 2009 and 2015 based on levels of participation in INIAP Andean Grains Promotion Project.

note that there continues to be increases in the use of INIAP varieties, presumably as they become more available and accepted as superior by more farmers.

The differences in the percentage of farmers surveyed that cultivate lupin and quinoa and who adopted the improved varieties also vary as a function of the level of participation in the INIAP Andean grain promotion project. Within the groups that were identified by local leaders as having a 'high participation' in project activities, there is a greater frequency of planting and use of the INIAP varieties. There are less substantial increases amongst the intermittent and low participation groups over the baseline in terms of sowing quinoa and lupin in general, but there are gains in this group in terms of using INIAP varieties (Figure 5).

\section{DISCUSSION}

The success of INIAP's interventions are noteworthy: three farmers groups now provide upwards of $7 \%$ of the country's seed for quinoa and lupin, up from virtually nothing; the farmers receive a $36 \%$ price premium for the seed they produce; and farmers have increased their utilization of Andean grains in general (over 20\%) and INIAP varieties in particular (over 30\%). INIAP's failures to have influence, namely with Catholic farmers in Ninin Cachipata and the eight communities in Chimborazo who did not decide to continue to work with them are equally instructive. Interestingly, it is precisely the lack of bridging social capital within a community that can lead to this type of deep divisions based on gender, age, race, religion or other less obvious variables. This paper attempted to pull apart the factors that influenced 
Table 5. Comparative capitals in three Andean grains seed systems.

\begin{tabular}{lccc}
\hline & Existing/starting capital & Developed capital & Leveraged capital \\
\hline Ninin Cachipata & $\begin{array}{c}\text { Social (bonding), cultural } \\
\text { (religious), natural (good }\end{array}$ & $\begin{array}{c}\text { Intellectual (new knowledge), } \\
\text { built, social (bridging), }\end{array}$ & Financial \\
& conditions for lupin) & natural (new varieties) & \\
CORPOPURUWA & $\begin{array}{c}\text { Political (private land), natural } \\
\text { (good conditions for lupin) }\end{array}$ & $\begin{array}{c}\text { Intllectual (certification), } \\
\text { human, social (bridging), }\end{array}$ & $\begin{array}{c}\text { Social, financial, } \\
\text { human, built }\end{array}$ \\
& & natural (new varieties, \\
financial (successful business) & & \\
APROSANAMY & Social, cultural (value local & Natural (new varieties), human & Financial, built \\
& foods), natural (good & (capacity) & \\
& conditions for quinoa) & & \\
\hline
\end{tabular}

those results to better inform future interventions. These three case studies show that different seed system options were developed that fit the local contexts. Another level of Options x Contexts occurred in terms of the research and extension approaches of INIAP in each of the three sites. Through the use of a capitals analysis to assess starting, developed and leveraged capitals during a long-term intervention, we can appreciate that there is preliminary evidence that more tailored approaches that respect local conditions might lead to more endogenous and sustainable development patterns.

The objective of Table 5 is not to highlight what capitals are missing, but rather to reflect on what capital options (leveraged capitals) are most suited to what capital contexts (existing capitals) to develop new capitals (developed capitals.) Table 5 suggests that the most salient starting capitals for a seed system intervention appear to be social, cultural and natural. The value added of a research organization might be in providing natural capital in terms of new varieties to be tested and intellectual and human capital through participatory research and extension. Perhaps of equal or even greater importance in these case studies was the ability of INIAP to connect the farmer groups with potential buyers by providing bridging social capital. This role is not usually assumed by research organizations and might need to be studied in other contexts to fully understand its importance. The mix of starting and developed capitals can then fuel the farmer organization to invest and improve other capitals on their own such as financial, built and even social capital, creating an upward spiral of sustainable development. Appearance of financial capital in both leveraged and developed capitals for the first two cases, shows how this spiral keeps growing as initial cash investments lead to more money making activities. This could support Witcomb et al.'s findings in Nepal that seed producers were able to leverage the natural capital (seeds), and human capital (capacity building on marketing and managerial skills) that an outside organization provided them to achieve sustainability through their saving and increasing financial capital (2010).

Intuitively, through trial and error, INIAP and their local partners arrived at different participatory research strategies for each of the three groups based on contextual factors. However, an initial diagnosis could have been done more 
purposefully, which would have arguably led to even better interventions and outcomes. In both the cases of Ninin Cachipata and Guamote, only about 20-25\% of the farmers who were first contacted showed interest and continued working with INIAP. With a better understanding of the local context, INIAP could have developed research and extension options to target the Catholic farmers in Ninin Cachipata and those with communal lands in Guamote, or at least not alienate them. Of course, as Andrea Cornwall carefully explains in her article 'Unpacking participation', there is not just one type of participation and often there is self-exclusion due to a myriad of reasons. Thus, interventions should not take the stance that everyone will want to participate, but rather try to understand who is participating and not, and for what reasons (2008), which is an important aspect of contextual diagnosis.

In organizations where social capital is already established like APROSANAMY, perhaps the intervention can be adjusted so that more is done with demonstration plots that require less time than participatory research and then local networks could take over the role of innovation and experimentation. Participatory research approaches represent an option, but maybe not always the best option for a particular context, sometimes technology transfer represents the better option. Although the adoption of INIAP varieties by farmers who had low participation in the intervention supports the hypothesis that local networks and processes are also effective dissemination mechanisms, more research would be needed to confirm this hypothesis.

The continued growth in the use of INIAP varieties in Ninin Cachipata, even after INIAP stopped actively working with a community indicates the strength of participatory research options adapted to different contexts. An impact that rarely gets measured in a seed system intervention is the ability of the organizations to capitalize on that outside intervention to continue to develop and sustain their advances. The PRONALEG-GA group of INIAP is very atypical for a research institute in their recognition of and affinity for farmer outreach. This paper argues that not only has their approach been more successful than more on-station orientations, it can be improved upon by explicitly orientating their contribution to local populations as helping to catalyse the upward spiral of sustainable development. This entails adding value to the long term processes of a local context through research and extension options that both leverage existing capitals and can, in turn, be leveraged.

Acknowledgements. The authors express our gratitude to farmers in the provinces Cotopaxi, Chimborazo and Cañar for their positive participation in the whole process; the McKnight Foundation for their scientific and economic support, especially Claire Nicklin, Carlos Perez and Carlos Barahona for their unconditional commitment to Andean farmers and Marah Moore and Steven Vanek for their ample feedback on draft versions of this article; and INIAP, from the staff of the National Legume and Andean Grains Program, for their openness and support for the implementation of innovative experiences in research and development. 


\section{REFERENCES}

Almekinders, C., Louwaars, N. and de Bruijn, G. (1994). Local seed systems and their importance for an improved seed supply in developing countries. Euphytica 78:207-216.

Ashby, J. Y. (2001). La comunidad se organiza para hacer investigación. In Experiencias de los Comités de Investigación Agrícola Local, CIAL, en América Latina, 1-216. Cali, CO: Centro International de Agrícultura Tropícal (CIAT).

Badstue, L. (2007). Adquisición de semillas: el papel que juega la confianza. LEISA 23(2):14-17.

Baranski, M. (2015). Wide adaptation of green revolution wheat: International roots and the Indian context of a new plant breeding ideal, 1960-1970. Studies in History and Philosophy of Biological and Biomedical Sciences 50:41-50.

Braun, A. R., Thiele, G. and Fernández, M. (2000). Farmer field schools and local agricultural research committees: complementary plataforma for integrated decision-making in sustainable agriculture. Agricultural Research $\mathcal{E}^{\circ}$ Extension Network. Paper No. 105. London, UK: Overseas Development Institute (ODI).

Castelloe, P., Watson, T. and Allen, K. (2011). Rural Networks for Wealth Creation: Impacts and Lessons Learned from US Communities, Asheville: Rural Support Partners.

Cornwall, A. (2008). Unpacking 'participation': models, meanings and practices. Community Development fournal 43(3):269-283.

Council, N. R. (1989). Lost Crops of the Incas: Little-Known Plants of the Andes with the Promise for Worldwide Cultivation. Washington, DC: National Academy Press.

Emery, M. and Flora, C. (2006). Spiraling-up: mapping community transformation with community capitals framework. Community Development 37(1):19-35.

Franco, J. and Main, G. (2008). Management of nematodes of andean tuber and grain crops. In Integrated Management and Biocontrol of Vegetable and Grain Crops Nematodes, 99-117. Netherlands: Springer.

Granovetter, M. S. (1973). The strength of weak ties. American fournal of Sociology 78(6):1360-1380.

Guitiérrez-Montes, I. (2005). Healthy communities equals healthy ecosystem? Evoluation (and breakdown) of a participatory ecological research project towards a community natural resource management process, San Miguel Chimalapa (México). Phd Dissertation ed. Ames: Iowa University.

Horton, D. (2014). Collaborative Crop Research in Action: A Study of the McKnight Foundation's Support for Andean Grains Research and Development in Bolivia and Ecuador, Minneapolis: The McKnight Foundation.

Junovich, A. (2003). El Cultivo Del Chocho a Través de Los Datos Del III Censo Agropecuario, Quito: s.n.

Louwaars, N. (1994). Integrated seed supply: a flexible approach. In Seed Production by Smallholder Farmers, 39-45 (Ed J. Hanson). Addis Adaba: International Livestock Centre for Africa.

Mazón, N., Peralta, E. and Rivera, M. edits., (2011). Sistema De Bancos Locales De Semillas: Bases, Principios y Manual De Funcionamiento. Guamote (Chimborazo): s.n.

Nayaran, D. (1999). Bonds and Bridges: Social Capital and Poverty, Washington: World Bank.

Nicklin, C., Rivera, M. and Nelson, R. (2006). Realizing the potential of an Andean legume: roles of market-led and research-led innovations. International Fournal of Agricultural Sustainability 4(1):61-78.

Patton, M. P. (2011). Developmental Evaluation: Applying Complexity Concepts to Enhance Innovation and use. New York: Guilford.

Peralta, E., Mazón, N., Murillo, Á. and Rodríguez, D. (2014). Manual Agrícola De Granos Andinos: Chocho, Quinua, Amaranto y Ataco. Cuarta ed. Quito (Pichincha): s.n.

Pumisacho, M. and Sherwood, S. edits., (2005). Guía Metodológica Sobre ECAs. Quito: s.n.

SIISE, (2015). Sistema Integrado de Indicadores Sociales. [Online] Available at: http://www.siise.gob.ec/siiseweb/ [Accessed June 8 2015].

Snapp, S., Blackie, M. and Donovan, C. (2003). Realigning research and extension to focus on farmers' contraints and opportunities. Food Policy, 28(4): 349-363.

Stromberg, P., Pascual, U. and Bellon, M. (2010). Seed systems and farmers' seed choices: the case of maize in the peruvian amazon. Human Ecology 38(4):539-553.

Thiele, G. (1999). Informal potato seed systems in the Andes: why are they important and what should be do with them? World Development 27(1):83-99.

Witcombe, J. (2010). Linking community-based seed producers to markets for a sustainable seed supply system. Experimental Agriculture 46(4): 425-437.

Yin, R. K. (2009). Case Study Research: Design and Methods. 4th Edn. Thousand Oaks: Sage. 